\title{
Determinants of Female Labour Force Participation in Cameroon
}

Gladys NJANG CHE $^{1^{*}}$

Fabien Sundjo $^{2}$

'State-owned University of Bamenda-
Cameroon.
Email: gladys.njang@yahoo.com
${ }^{2}$ Researcher, and lecturing at the State-
owned University of Buea, Bamenda
and YaoundéII-Cameroon.
Email: sundjofabien@,rocketmail.com

Licensed:

This work is licensed under a Creative Commons Attribution 4.0 License.

Keywords:

Labour market,

Female participation and logit

regression model.

\begin{abstract}
Recently, women have become relatively more engaged in the labour market and this increasing trend toward women's participation in jobs in the third world countries has drawn both social and academic attention. It is on the bases of this context, that this paper purports to empirically investigate the determinants of female labour force participation in Cameroon. Specifically, the study attempts to scrutinise the effect of: (a) spouse working status, (b) mothers/household characteristics, and (c) the type of religion practiced, on female labour force participation. To ascertain these objectives, data is sourced from the 2011 Cameroon Demographic Health Survey data collected by the National Institute of Statistics (NIS) and used is made of both descriptive and inferential statistics. The logit regression model is employed to test the objectives. The empirical findings, among others suggested that, a woman with a non-working husband, an increase in age, presence of woman in the household increases the likelihood of women participating in the labour market. Contrarily, the presence of young children aged $0-5$ years in the household and being a Muslim reduces the likelihood of women participating in the labour market. Policy wise, it is important for policy makers to understand women's decision to supply labour in the labour market as well as the factors that enable them to either participate or not in the job market.
\end{abstract}

Funding: This research entitled 'Determinants of Female Labour Force Participation in Cameroon, was Funded by the researchers due to their profound interest in the subject matter.

Competing Interests: Both authors contributed equally to the conception and design of the study.

\section{Introduction}

Recently, women have become more engaged in the labour market and this increasing trend toward women's participation in jobs in the third world countries has drawn both social and academic attention (Sunghee, 1991). Moreover, the participation rate of females in jobs is much lower than for men in many countries. These differences to some extent are rooted in culture and social norms, but they also reflect economic incentives (Ruhm, 1998). Also, with changing economic situations it became difficult to financially support a family with a single income. Probably family members (mother) other than the father, the "bread winner" had to enter the labour force to earn sufficient money to support the family. Therefore the role of in assuring the welfare of households is of significant importance in the reduction of poverty.

Nowadays with increasing number of women entering the labour force women are more socialized working in the same environment with men, and having more power within the family is perceived as more normal today than it used to be. In the world today, women account for more than half of the world's population, perform two-thirds of the hours of work, receive one-tenth of the world's income, and have less than one hundred of the world's property registered in their names. According to International Monetary Fund (2013) the average gender participation gap (the difference between male and female labour force rates) is on a decline since the 1990 s.

The presence of females in the labour force has attracted the attention of economic analyst ever since it was examined by Psacharopoulos and Tzannatos (1989); Tansel (2001) and Boserup (1970). The participation of females in the labour force is crucial in the examination of female labour behaviour in the household. Killingworth and Heckman (1986) explained that the behaviour of female labour supply has important implications for many other phenomena, including fertility, marriage, divorce, the distribution of family 
earnings, and female-male differentials'. Presently, female labour force participation has become a necessary element in the determination of the performance of economic development, both in Developed and in Developing countries. To some economists there is a strong link between female labour force participation and economic development, and also between female labour force participation and aggregate efficiency. Wherein female labour force participation leads to increases aggregate efficiency as well as the development of the country. Women's role is therefore significant in poverty reduction because of their role in assuring the welfare of households. However, this study seek to explain some of the factors that determine female labour force participation in Cameroon.

In Cameroon women make up a little over half of the population, but shockingly their contribution to economic activity, growth, and well-being is far below its potential, with serious macro-economic consequences. Women account for most unpaid jobs, and even when they are employed in paid jobs, they are over represented in the informal sector where they face significant wage differentials among their male colleagues. This situation therefore hinders female representation in senior positions and entrepreneurship remains low. Therefore better opportunities for women to participate in the labour market can also contribute to broader economic development especially in Cameroon, for example through higher levels of school enrolment for girls IMF(2013).

In most countries women contribute much less than men towards the value of recorded production both qualitatively in the labour force, and qualitatively in educational achievement and skilled man power (Olukemi, 2008). Female deprivation in particularly acute in the developing countries with high levels of poverty, though in affluent nations women also suffer low status due to conservative attitudes. Despite the significance of female labour force participation for the development women, this rate has remained substantially lower than the rate for men in the world. This rate difference stood at 68 women per 100 men participating in the wage earning productive activities in the year 2001 (United Nations Development Fund UNDP, 2003). From the UNDP report of 2003, this rate varies greatly from one country to another. This indicates that there is a lower rate of female participation in the labour market in developing countries, and higher rate in the developed countries. A high male unemployment may stimulate female participation as women join the labour force in order to compensate for the loss of family income arising from the fact that their husbands are not employed ( the $<<$ added worker $>>$ effect). The female labour force participation is less than the male labour force participation because women have lower opportunity costs of low participation when faced with situations of low wages. Most often unemployment rates are higher among women because they have low opportunity cost of getting a job arising from discrimination in employment (Addison, 1993).

In Cameroon, the World Bank (2013) show that the literacy rate of females aged 15 years and above is $68 \%$. Fewer girls are in secondary schools compared to boys with an $80 \%$ ratio of female to male secondary school enrolment. More than half of the adult women participate in the agricultural and educational sectors especially teaching in primary schools. Considering the different sectors of the labour market in Cameroon, the informal sector has the highest proportion of women, reason being that jobs in the formal sector in Cameroon is contingent on participants education and skills acquisitions, and also on requirements that tend to be met more by males than females for various reasons (precisely; financial, institutional, cultural, and institutional). According to studies carried out by the department of Human Resource of the University of Yaounde II Soa in analysing female labour force participation in urban Cameroon, it was realised that out of 2096 women aged 18-64 living in Douala and Yaounde, 59.92\% are working and 43.08\% are not working

According to Njimanted and Mukete (2016b) the trend of male labour supply in Cameroon exceeds the female labour supply within the period 1980-2015. According to these authors, since 1980, female labour supply was approximately $40 \%$ of the female population aged 15 years and above, and increased a little to $52 \%$ in 1990. From 1990, it increased slightly to $53 \%$ and has remained constant up to 2010 and then decreased in 2015 which is a call for concern.

Even though many studies have been done in Cameroon on the determinants of female labour force participation, most have used the multinomial logit model, others the Generalised Method of Moment Technique, and the Vector error correction model using different data sets, like ECAM. This study makes a difference by employing a different data set which is the most recent Demographic household Survey Data of 2011 in analysing the determinants of female labour force participation, which most of the studies did not do. This study attempts to provide answers to the following main question: Which factors determine female labour force participation in Cameroon? Following the major research question, for formulated the subsequent specific questions:

- What is the effect of the employability of the spouse on female labour force participation?

- What are the effects of mother/household characteristics (birth in past year, age of mother, number of females in the household, marital status, number of children under five) on female labour force participation?

- What are the differential effects of religion on female labour force participation across residence?

The main objective of this paper is to examine the determinants of female labour force participation in Cameroon. Specifically the objectives are: 
- To assess the effect of the employability of the spouse on female labour force participation in Cameroon and across residence.

- To investigate the effects of mother/household characteristics on female labour force participation in Cameroon and across residence.

- To scrutinise the differential effects of religion on female labour force participation across residence. These objectives are guided by the following testable hypotheses, stated in alternative form:

- The partner's employability is expected to relate negatively with FLFP

- Mother's household characteristics have a positive effect on FLFP

- We expect Muslims to participate less in the labour market than Christians.

The remaining sections of this paper is structured as follows: section II focus on the literature reviews, section III presents the methodology and the data description is done in section IV while section V present the findings and section VI concludes the paper.

\section{Literature Review}

This section attempts to review the literature pertaining to the labour supply theory, as well as issues regarding female labour force participation. Faridi, Chudhry, and Malik (2011) investigated the factors that influenced women's participation in self-employment in Pakistan, and concluded that education, location, and numbers of dependents significantly reduce the women's work participation as self-employed workers.

Lisaniler and Bhatti (2005) in their investigation of the determinants of female labour force participation in North Cyprus for the year 2001 realised that women's education is the main determinant of job participation, while age and the residence are also significant factors influencing the women's labour supply. Another study by Fatma and Eyza (2005) still in North Cyprus, given its low population with the female population outweighing the male population, fewer women are still being found in jobs than men. Even though the total occupational gender segregation increased by 3.5\% over the period (2004-2010). However, this increase was more experienced in the urban areas, while this situation did not change in the rural areas, due to the fact that the jobs that were available for women in the rural areas were low paying and less productive jobs.

Meltem and Kirdar (2010) realised that the female participation rate in the labour force in Turkey is low. Despite the declining trend, the participation rate in the rural areas is still higher than that in the urban areas, which has been more stable over time. In the urban areas this increase is been experienced only in particular age groups (25-29 years). In Egypt, women are likely to work before they get married. This is due to the fact that there is a high cost of marriage in this country, and one of the main reasons why Egyptian women have to work so as to be able to afford this cost. When these women get a job before marriage, they make some money which goes a long to assist the husband in paying the dowry (Hendy, 2011).

Studying the impact of education on female labour force participation and other personal and household factors on Egyptian female's population. Hosny (2007) compares these determinants with those of Germany. Suggestions from the study insinuate that in order to have more participation of females in jobs, females should acquire higher general high school and university education, or better still be enrolled in vocational high schools from where they can gain direct entry into the labour market. Some household characteristics like single mother, working in the rural areas, previous work experience, and if the woman's mother is employed has a positive relationship with female labour force participation. Considering the household characteristics with respect to German and Egyptian female labour force participation and given the fact that women participate in the labour market varies greatly across countries, the study concluded that the variable years of schooling had a higher marginal effect on the Egyptian female labour force participation, while other factors such as marriage and number of children had a higher marginal effect on German female labour force participation.

In assesses the impact of female Labour force participation on the Economic development of a group of Southern Mediterranean countries. This study makes use of many determinants that have led to this low rate of women in the job market, but completely neglects fertility which is a very important determinant of female Labour force participation. This study, like many others, neither considers the respond of increased demand for children to female Labour force participation. This research work attempts to provide inputs in this direction (Tsani, Paroussos, Fragiadakis, Charalambidis, \& Capros, 2012).

The education of females in Brazil is an important factor that determines their participation rate. The impact of schooling here is regarded as a trade -off along two panels. In the first panel, is the relationship between home productivity and labour market productivity, which explains that more educated women easily find well paid jobs. The second panel concerns the adjustment that has to be made in terms of child quality and quantity resulting from the effects of schooling on home productivity (Lam \& Duryea, 1999).

In Japan and Korea, female labour force participation depends on regular and non regular employment, which indicates that child cash allowances tend to reduce the proportion of regular female employment. While the persistent gender wage gap encourages more non-regular employment, higher fertility encourages regular female employment (Kinoshita \& Fang, 2015). In same light, results from a study by Yuko and Fang (2015) 
are used to compare these two Asian countries with two Nordic countries (Finland and Norway). The results show that there is need for more public spending on childcare for age 6-11 years in Japan and Korea that will enable women to work in regular employment

Looking at the formal sector in Pakistan, a study by Khadim and Akram (2013) using a logistic model suggested that a female's decision to participate in the formal sector is influenced by secondary and tertiary level of education and most especially the post graduate level. Furthermore, the results revealed that factors such as marriage, urban area residence, belonging to a family with many sisters have a positive impact on female participation, while other factors such as presence of boys at home and the woman as head of the family has a negative impact on female's participation in the formal sector. The study therefore concludes that education for women may be the main policy available for a greater participation of women in the job market.

Employing a cross-sectional data on female ages 10-65, gotten from the labour force survey for the year $2005 \backslash 2006$ in Pakistan, Mujuhid (2014) looked at the determinants of female labour force participation from the point of personal household characteristics. The study revealed that the more educated a woman is the more chances she would have in participating in the labour market. The results also showed that elderly women have higher wages, have more training and experience which increases their opportunities of working in the labour force than younger women. The study therefore encourages investment in female education, which will go a long way to increase female job participation and also their wages.

In India different ethnic and socio cultural groups tend to concentrate in various sectors of the labour market. This result is from an investigation done by Surjit and Kaur (2011) on the determinants of female labour force participation in India. Another study carried out by Steven, Andrea, and Evangelia (2014) still in India shows that there is a sharp decline in female labour force participation, attributed to increased attendance in education, and higher household incomes. Also, there is evidence that changes in measurement methodology across survey rounds is likely to have contributed to estimated decline in female participation . This arises due to the difficulty in differentiating domestic duties, and contributing family work. But then the key long-run problem is the lack of employment for India's women owing to factors such as occupational segregation.

A study in India show that child mortality can be reduced by medical factors, more than non-medical factors, which is achieved through vaccination, medical care at birth, and the preventive and curative medical care during the post neo-natal period. Therefore laying emphasis on the fact that infant mortality can be curbed by simple preventive medical interventions (Jain, 1985).

In assesses the impact of female Labour force participation on the Economic development of a group of Southern Mediterranean countries. This study makes use of many determinants that have led to this low rate of women in the job market, but completely neglects fertility which is a very important determinant of female Labour force participation. This study, like many others, neither considers the respond of increased demand for children to female Labour force participation. This research work attempts to provide inputs in this direction (Tsani et al., 2012).

Boserup (1990) argued that in developing countries, the bulk of women's work takes place in non-market activities in the home or the informal sector. However in some developing countries women participation in the labour force has increased due to three reasons. First, with economic development and the ensuring shift of population from rural and agricultural sectors, more women choose to participate in the labour force. Second, due to higher level of education women tend to participate in greater numbers in order to capture returns on their investment. Third, falling real incomes of households and rising poverty in certain countries seem to have persuaded women to participate in the labour force in greater numbers.

The factors that encourage and discourage women from work have been analysed by Verena, Sonam, and Yusraa (2011) using household survey data and logistic regression modelling for Mauritius from 20062008. Their findings corroborate with previous evidence for developing countries and indicates that the higher a woman's educational level, the better her ability to supply her skills for productive services, and that older women participate more though the rate of growth of this effect decreases. In addition, their study equally revealed that secondary education proves to be a significant determinant of female labour force participation in Mauritius. Their results also reveal that married women are less likely to participate in the job market. In fact, marital status is one of the most important factors averting them from work.

In a study by Andrei, Mirica, Teodorescu, and Dascalu (2016) on the Roma population in Bucharest, using the logit and probit models discovered that education was the main determinant of labour force participation among all ethnic groups in the Bucharest's labour market and especially for Roma. The results portrayed that the tertiary level of education had more influence on a woman's participation in the job market than the primary level of education.

A study by Mlatsheni and Leibbrandt (2001) in South Africa, on the female labour force participation found that divorced women are the most likely to seek employment, followed by married women, and lastly single women; reason being that these divorced women have little or no prospects of economic dependence. Still in South Africa (Ntuli, 2007) uses decomposition techniques devised by Even and Macpherson (1990) to show that female education is the prime factor influencing female participation. The study also finds that non- 
labour income, marriage, fertility, and geographical variations in economic development persistently stifled female participation in South Africa.

According to Yakubo (2008) in a study carried out in South Africa on Female labour force participation, the changes in the labour force was explained using a human capital theory which postulated that women's education is positively related to female labour force participation. From the study, there is a link between level of educational attainment and female labour force participation, which indicate that the higher the level of educational attainment, the more opportunities females in South Africa have in getting a job. This is regarded as a means to improve the status of women towards the achievement of Millennium Development Goal 3 (to promote gender equality and empower women).

In Bophelong town in South Africa, a study by Viljeon and Dunga (2013) looked at the determinants of unemployment status using logistic regression models. Analysing the factors that determine unemployment of females indicate that such factors will hamper female participation in the labour force. It was discerned that among the factors that among the factors that determine female unemployment household size, age, marital status, access to social grants and poverty status were found to be significant, indicating that these factors determine whether a woman can work or not.

Atieno (2006) analysed the determinants of female labour force participation in the case of the informal sectors in Kenya, using the multinomial logit model. The results from this investigation show that education, represented by years of schooling increases female's chances of being employed in the public and private sectors. The results also show that land ownership by women increased their chances of being in the agricultural, public and private sector, and unpaid family work, but not in the informal sector as many people will think.

Using a probit model to investigate the determinants of female labour participation in Ghana, Sackey (2005) concludes that improvements in the educational status of females (in terms of both enrolment ion schools and the years spent in schooling) as well as the tendency towards later marriage have been crucial to fertility reduction in Ghana. The gap in education between females and males has become smaller over the years, explained by the fact that more females get involved in the labour market than it was the case before. The fact that many girls are enrolled in schools in both the urban and rural areas, give them a double advantage of securing jobs in the future. Still in Ghana another study on the determinants of labour force participation of women at two points in time, that is 1991 and 2006 realised that women's labour participation is determined by fertility and educational attainment. Women with children are reluctant to look for jobs, while women with higher levels of educational attainment have more opportunities of getting a job (Ackah, Ahiadeke, \& Fenny, 2009).

In Nigeria, Iweagu, Yuni, Nwokolo, and Bulus (2015) looks at the participation of women in jobs with respect to the urban and rural sectors, and found that factors such as marital status, religion, poverty rate and per capita income were the significant determinants of female participation in the rural area, while age and literacy rate were the main determinants in the urban sector. Still in Nigeria, Baridam (1996) examined the determinants of female labour participation and opines that women participation in the labour force is due to economic agents, and love for children. Similarly, Olusoji (2006) investigated these determinants of female labour participation using a survey carried out between January and October 2001, and his results analyses on differences in hours put in by both women in the informal and formal sectors depending on the household size, income, sector of participation, education, and location. The findings show that women with tertiary education work fewer hours than older and married women. Olowa and Adeoti (2014) discovered in rural Nigeria that female education is necessary to ensure effective participation of women in the labour market. The results reveal that most educated females in rural Nigeria have a high probability of getting a job.

The presence of women in leadership positions at the secondary school level in a study carried out in Uganda contributes positively to the wellbeing of adolescent girls, since these women are versed with the problems faced by adolescent girls ( for example cultural and religious beliefs, discrimination, and sexual harassment). These women act as a source of inspiration to young girls, and this go a long way to help them choose better careers in life, and therefore easily get involved in jobs (Hannah, Ayodo, Tikoko, \& Enose, 2014).

In Sudan, a study carried out by Maglad (1998) examining the economic variables determining women's decision to enter market activities, draws conclusions that the decision for a woman to join the labour market were based on the wage she will receive depending on her education. It is evident from the results that among other factors like; presence of small children and older children that determine female participation in the work force, education was outstanding. Female participation and labour supply decisions had a positive relationship with own wage, but the negative relationship with the spouse's wage.

A study carried out in Cameroon by Ngeh (2016) on the determinants of female labour force participation and sectoral choices, using a multinomial logit model show that females who have tertiary education and who reside in the urban areas more likely to work in the industrial, commerce and service sectors. After examining factors like education, marriage, offspring that affect female participation in jobs positively, Bibi and Afzal (2012) suggests that the prevailing rate of inflation in the economy of a country influences the labour force participation of married women greatly. Again, in Cameroon, another study by Njimanted and Mukete (2016a) employed a time series approach for 37 years (1980-2014). The study used data provided by 
the World Bank (for the year 1980-2014), with the help of the Generalised Method of Moment Technique and Vector Correlation Model to capture the determinants of female labour force participation and its effects on economic growth. Their study show that female labour force participation is determined by factors such as dependency ratio, fertility rate, male labour force participation and per capita income, and its effect on economic growth differs with respect to the female and male participation rates.

Fertility burden prevents women from accessing high job status in both Sahelian countries like Mali and Senegal. In Cameroon, however, fertility is not a direct obstacle to female performance in the Labour market (Kuepie, Dzossa, \& Kelodjoue, 2013). However, evidences on how fertility will respond to increasing participation of women in the labour force and significant child mortality constitute crucial inputs in Cameroon's current public policy.

Zama-Akono (2009); Kuepie et al. (2013) on female labour force participation in Urban Cameroon concluded that fertility has a positive impact on female labour force participation and that most women who work for pay have fewer children than women who do not work for pay. This study focused attentions on the impact of fertility on female labour Force participation but ignored the influence of female labour force participation on fertility. This study will attempt to complement the literature by examining the impact of female labour force participation on fertility in Cameroon.

Also, it is important to note the non-economic aspects of female labour force participation (especially religion) have tremendous effects on an economy. Countries with the lowest rate of women in labour market participation are those with strong religious views (like women staying at home and taking care of children, their style of dressing etc) about women in society, and business in particular. Some scholars have concluded that different religions have an influence on economic attitudes and female decisions to sectors of employment (Chadwick \& Brent, 1993; Guiso, Sapienza, \& Zingales, 2003; H'madoun, 2010). Our study considers the effect of religious belonging on female labour force participation and innovatively tracks this effect across residence to capture the differential effect of this potent variable.

H'madoun (2010) specified and estimated a probit model with a vector of religious variables among other exogenous predictors to examine the influence of religion on female labour force participation across countries. The data for the study were obtained from the 2005 wave of the World Value Survey, where 26,711 women in the age group of 18- 55 years in 48 countries were selected for the study. Like many other studies of this nature, the religious women were found to be less involved in labour market activities than their non-religious counterpart, after controlling for other social and economic variables in the model. Though this study is informative, one of its main limitations is the fact that all the 48 countries were lumped together in the analysis without being disaggregated for country- specific peculiarities. Even when one of the regression equations reported country-fixed effects, no clear explanation was given for how this study was carried out. Fortunately, our study will complement the literature on female labour market participation by providing country-specific knowledge on this issue.

Education is unquestionably the most fundamental and important form of human capital investment, which emphasizes the characteristics of the individual as an important determinant of work. Education and participation in the workforce both depend on and affect a country's economic and general development. There is a positive relationship between education and female labour force participation (Atieno, 2006; Sackey, 2005). Also, there is a stronger tendency for a more educated woman to remain economically active than a less educated woman (Oluwasey, 2013; Siphambe \& Motswapong, 2010).

\section{Methodology}

A logistic regression analysis is employed given that the dependent variable, female labour force participation $(\mathrm{F})$ is dichotomous or binary and takes values 1 for a woman who is employed and o for a woman who is unemployed. The relationship between the dependent and the independent variable is specified using discrete model of probability, which generally looks at the chances that an event will occur. This gives us the following probabilities

$\operatorname{Prob}(\mathrm{F}=1 / \mathrm{X})=\mathrm{P}$, being the probability of the event that the woman is employed and;

Prob $(\mathrm{F}=\mathrm{O} / \mathrm{X})=1-\mathrm{P}$, being the probability of the event that the woman is unemployed.

Where; $\mathrm{P}(\mathrm{F}=1 / \mathrm{X})=\frac{1}{1+\mathrm{e}^{-\alpha-\sum \beta \mathrm{iXi}}}$

$\mathrm{P}(\mathrm{F}=\mathrm{O} / \mathrm{X})=1-\mathrm{P}(\mathrm{F}=1 / \mathrm{X})$

The notion of the odd ratios is therefore inevitable for our understanding. The odd ratios is given by; Odd Ratios $=\mathrm{e}^{\beta_{\mathrm{i}}}$; the odds ratio alongside the value of coefficients and probabilities will be employed for the purpose of interpreting results.

Odds $=\frac{P}{1-p}$, which is defined as the ratio of the probability to its complement. Calculating the logit of the

$\log$ odds gives us; 
Logit $(\mathrm{P})=\log \left(\frac{P}{1-P}\right)$. This implies that as the probability goes down to zero, the odds approach zero and the

logit approaches $-\infty$. At the other extreme, as the probability approaches one, the odds approach $+\infty$, and so does the logit. Negative logits represent probabilities below half and positive logits represent probabilities above half. As such, the logistic regression model is specified as follows:

$\log \left(\frac{P}{1-P}\right)=\beta_{0}+W \gamma+\varepsilon$

Where: $\log$ represent logarithm; $\mathrm{P}$ the Probability of the woman being employed; $\mathrm{P} / 1-\mathrm{P}=$ odd ratio, being the probability that the woman is working over the probability that the event does not occur. W is the vector of independent variables, $\beta_{0}$ the constant term and $\gamma_{s}$ a vector of parameters to be estimated and $\varepsilon$ captures

other variables which relate with the dependent variable but which are not included in the model. The vector W include variables like the level of education, Births in past year, Age of mother, Number of children,

Husband working status, Marital status, Poverty, Children under 5, Muslim and ethnicity. As concern the description of the variable in the model, and how it was coded, Table 1 below is employed for that.

\begin{tabular}{l|l} 
Table-1. Description of Variables and how they were Coded. \\
\hline Variables & Description \\
\hline Dependent variable & \\
\hline Female labour force participation & 1 if woman is employed and o if woman is unemployed \\
\hline Independent variables & \\
\hline Education & Categorical \\
\hline Primary education & Binary \\
\hline Secondary education & Binary \\
\hline University education & Binary \\
\hline Births in past year & Continuous \\
\hline Age of mother & Continuous \\
\hline Number of Females & Continuous \\
\hline Husband working & 1 if husband is not currently working and o if husband is currently \\
\hline Married & working \\
\hline Socio economic status & 1 if married and o if not married \\
\hline Children under 5 & 1 if household is poor and o if household is rich \\
\hline Muslim & Continuous \\
\hline Ethnicity & 1 if Muslim and o otherwise \\
\hline Source: Computed by authors using DHS 2011. & 1 if pygmy and o otherwise \\
\hline
\end{tabular}

\section{Data Used}

The study employs the Demographic and Health Survey data conducted by the National Institute of Statistics (INS) in 2011. These Demographic and Health Surveys were conducted through representative sampling at the national level. The data provide detailed information on fertility, family planning, maternal and child health, nutritional status of children aged less than three years, infant and child mortality and maternal mortality. The survey was conducted in both urban and rural areas, and covered all the ten regions of Cameroon.

The 2011 Cameroon Demographic health Survey combined with Multiple Indicators Clusters Survey (2011 DHS-MICS) was implemented by the National Institute of Statistics (NIS) from January 2011 through August 2011. ICF Macro provided technical assistance through the major DHS program, a project funded by the United States Agency for International Development (USAID), which provides support and technical assistance in the implementation of population and health surveys in countries worldwide. The 2011 DHS was funded by the Cameroon Government with the support of UNICEF (United Nations Children's Fund), UNFPA (United Nations Population Fund), World Bank and the USAID.

The 2011 DHS-MICS is a follow-up to the 1991, 1998 and 2004 DHS surveys and 2000 and 2006 MICS surveys which provides updated estimates of basic demographic and health indicators and children situation in Cameroon. However, the primary objective of the 2011 DHS-MICS project is to provide high-quality data on fertility levels and preferences; family planning use; reproductive, child and maternal health; nutritional status of young children and women; childhood mortality levels; ownership and use of mosquito bed nets, prevalence of malaria; prevalence and treatment of childhood illness; fistula, domestic violence, knowledge, behaviour and regarding HIV/AIDS and prevalence of HIV/AIDS; maternal mortality; and woman participation in social life. 
The sampling frame employed for the 2011 DHS-MICS is the 2005 Population and Housing Census. The sample excluded nomadic and institutional populations, such as persons staying in hotels, barracks, and prisons. The sample was designed to allow estimates of key indicators for each of Cameroon's 10 regions, the main towns Douala and Yaoundé due to their population were considered as separates regions. To achieve this objective, the sample was selected in two stages. In the first stage, 580 sample points (or clusters) were randomized selected and 578 of them were effectively visited. In the second stage, 24 households in each urban cluster and 28 households in each rural area were selected from each sample point in all regions. A household listing operation was undertaken in all the selected areas in June and September 2009. From these lists, households to be included in the survey were selected. The sample design resulted in a total of 15,060 households selected. In all households, women age 15-49 were eligible for interview. Every second household was selected for the men's survey. In these households, all men age 15-59 were also eligible for interview. Of the 15,060 households selected, 14,354 were found to be occupied. Of the 14,354 occupied households, 14,214 were successfully interviewed, yielding a household response rate of 99 percent. In the interviewed households, a total of 15,852 women were identified to be eligible for the individual interview, and 97 percent of them were successfully interviewed (corresponding to 15,426). For men, 7,525 were identified as eligible for interview, and 96 percent of them were successfully interviewed (corresponding to 7,191).

Worthy of note, due to the approximately equal sample sizes in each region, the sample is not selfweighting at the national level and weighting factors have been added to the data file so that the results are proportional at the national level. The 2011 DHS-MICS used three questionnaires: Household Questionnaire, Woman's Questionnaire and Man's Questionnaire. These questionnaires were based on the standard DHS and MICS surveys questionnaires, adapted to reflect the population and health issues relevant to Cameroon. Inputs were solicited from various stakeholders representing government ministries and agencies, non-governmental organizations, and international donors.

5. Presentation of Empirical Findings

5.1. Descriptive Statistics for Overall and Sub Samples

Table-2. Summary Descriptive Statistics: Overall Sample.

\begin{tabular}{|c|c|c|c|c|c|}
\hline Variable & Observation & Mean & Std. Dev. & Min & Max \\
\hline \multicolumn{6}{|l|}{ Dependent variable } \\
\hline Mother working & 11732 & 0.73031 & 0.443818 & $\mathrm{O}$ & 1 \\
\hline \multicolumn{6}{|l|}{ Independent variables } \\
\hline Primary education & 11732 & 0.418173 & 0.49328 & $\mathrm{O}$ & 1 \\
\hline Secondary education & 11732 & 0.305148 & 0.46049 & $\mathrm{O}$ & 1 \\
\hline University education & 11732 & 0.028043 & 0.165103 & $\mathrm{O}$ & 1 \\
\hline Births in past year & 11732 & 0.420815 & 0.521095 & $\mathrm{O}$ & 2 \\
\hline Age of mother & 11732 & 27.92942 & 6.76777 & 15 & 49 \\
\hline Number of females & 11732 & 3.970593 & 2.457704 & 1 & 15 \\
\hline Husband not working & 10905 & 0.00486 & 0.069548 & $\mathrm{O}$ & 1 \\
\hline Married & 11732 & 0.686669 & 0.463868 & $\mathrm{O}$ & 1 \\
\hline Socio economic status & 11732 & 0.448176 & 0.497328 & $\mathrm{O}$ & 1 \\
\hline Children under 5 & 11732 & 2.258098 & 1.413143 & $\mathrm{O}$ & 19 \\
\hline Religion (dummy for Muslim) & 11732 & 0.238834 & .4263893 & $\mathrm{O}$ & 1 \\
\hline Ethnicity (Pygmy) & 11732 & 0.0437266 & 0.2044948 & $\mathrm{O}$ & 1 \\
\hline
\end{tabular}

Table 2 reports the descriptive statistics for the overall sample. From the overall sample the descriptive statistics show that $73 \%$ of the mothers are working as opposed to only $27 \%$ who are not working. $42 \%$ of the women have the primary level of education, $31 \%$ have secondary level of education and $2.8 \%$ have the university level. For the births in the past year, we realise that a woman has an average of one birth in the past year.

The average age of the sampled women is averagely 28 years, and there are averagely 2 females in each household. The overall sample statistics show that $0.4 \%$ of the husbands are not currently working and $69 \%$ of the women are married. The socio economic status shows that $44 \%$ of households are poor in the overall sample. The average number of children under five years of age in the overall household is 2 .

The overall sample shows that $24 \%$ of the population are Muslims, while 76 are Christians. Concerning ethnicity, the overall sample shows that $4.3 \%$ of the population is made up of pygmies while $95.7 \%$ is made up of other ethnic groups. 
Table-3. Summary Descriptive Statistics: Rural Sub-sample.

\begin{tabular}{l|l|l|l|l|l}
\hline Variable & Observation & Mean & Std. Dev. & Min & Max \\
\hline Mother working & 7041 & 0.795058 & 0.403688 & 0 & 1 \\
\hline Primary education & 7041 & 0.465843 & 0.498867 & 0 & 1 \\
\hline Secondary education & 7041 & 0.19287 & 0.39458 & 0 & 1 \\
\hline University Education & 7041 & 0.005681 & 0.075163 & 0 & 1 \\
\hline Births in past year & 7041 & 0.439142 & 0.52605 & 0 & 2 \\
\hline Age of mother & 7041 & 28.06164 & 6.993394 & 15 & 49 \\
\hline Number of females & 7041 & 4.371822 & 2.581088 & 1 & 15 \\
\hline Husband not working & 6633 & 0.00392 & 0.06249 & 0 & 1 \\
\hline Married & 7041 & 0.72788 & 0.445083 & 0 & 1 \\
\hline Socio economic status & 7041 & 0.722483 & 0.447806 & 0 & 1 \\
\hline Children under 5 & 7041 & 2.424798 & 1.480576 & 0 & 19 \\
\hline Muslim & 7041 & 0.2505326 & 0.4333505 & 0 & 1 \\
\hline Ethnicity & 7041 & 0.0525494 & 0.2231479 & 0 & 1 \\
\hline Source: Computed by authors using DHS 2011. & & & & \\
\hline
\end{tabular}

Table 3 report the descriptive statistics for the rural subsample. The rural sub sample shows that $76 \%$ of the women are currently working, 46\% have primary education, $19 \%$ have secondary education and $0.5 \%$ has the university level of education. Therefore we realise that in the rural area, the higher the level of education, the lesser the number of women. For the births in the past year, we realise that a woman has an average of one birth in the past year.

The descriptive statistics show that the average age of the rural woman stands at 28 years, and there are averagely 4 females in each household. The rural subsample statistics show that $0.3 \%$ of the husbands are not currently working, and $73 \%$ of the women in the rural subsample are married. Concerning the socio economic status, the descriptive statistics show that $72 \%$ of households are poor in the rural areas. There are averagely more than 2 children under five years of age in the rural household.

The rural sample shows that $25 \%$ of the population are Muslims, while $75 \%$ are Christians. Concerning ethnicity, the rural sample shows that $5.2 \%$ of the population is made up of pygmies.

Table-4. Summary Descriptive Statistics: Urban Sub-sample.

\begin{tabular}{l|l|l|l|l|l}
\hline Variable & Observation & Mean & Std. Dev. & Min & Max \\
\hline Mother working & 4691 & 0.633127 & 0.482003 & 0 & 1 \\
\hline Primary education & 4691 & 0.346621 & 0.475945 & 0 & 1 \\
\hline Secondary education & 4691 & 0.473673 & 0.49936 & 0 & 1 \\
\hline University education & 4691 & 0.061607 & 0.240467 & 0 & 1 \\
\hline Birth in past years & 4691 & 0.393306 & 0.512394 & 0 & 2 \\
\hline Age of mother & 4691 & 27.73097 & 6.409855 & 15 & 49 \\
\hline Number of females & 4691 & 3.368365 & 2.122248 & 1 & 15 \\
\hline Husband not working & 4272 & 0.00632 & 0.079258 & 0 & 1 \\
\hline Married & 4691 & 0.624814 & 0.484223 & 0 & 1 \\
\hline Socio economic status & 4691 & 0.036453 & 0.187434 & 0 & 1 \\
\hline Children under 5 & 4691 & 2.007887 & 1.264971 & 0 & 8 \\
\hline Muslim & 4691 & 0.2212748 & 0.4151494 & 0 & 1 \\
\hline Ethnicity & 4691 & 0.0304839 & 0.1719329 & 0 & 1 \\
\hline Source: Computed by authors using DHS 2011 & & & & 0 \\
\hline
\end{tabular}

Source: Computed by authors using DHS 2011.

Table 4 report the descriptive statistics for the urban subsample. $35 \%$ of the women have primary level of education, $47 \%$ have secondary level of education and $0.62 \%$ has attained the university level. In the urban area we find more women with secondary education than they are in the rural area. Looking at the sub sample statistics, we realize that the average number of births for each woman since the past year is higher in the rural area compared to their counterpart in the urban area. For the births in the past year, we realise that a woman has an average of one birth in the past year. These statistics portray a typical example of the Cameroonian society with more births in the rural areas and few births in the urban areas.

The descriptive statistics show that average age for the rural woman is 27 years, and on average there are 3 females in each household. It is seen that the number of females in rural household exceed those in the urban household. The urban subsample statistics show that $0.6 \%$ of the husbands are not currently working. This is an indication that there are more husbands who are not currently working in the urban area than in the urban area. This may be as a result of the fact that most men in the urban area are in search of prestigious jobs and for this reason will prefer not to work, especially if the salaries are not encouraging while those in the rural areas are always ready to work, irrespective of the kind of job. 
$62 \%$ of the women in the urban subsample are married. This way, we find more married women in the rural area than in the urban area. This may be due to the fact that girls in the rural areas get married at an early age because their parents are reluctant to sponsor their female children for higher/university education. The socio economic status shows that $3.6 \%$ of households are poor in the urban area. This is an indication that poverty is more prevalent in the rural area compared to the urban area.

The average number of children under five years of age in the urban household is 2 . These values in the urban and rural samples specifically show that there are many children under the age of five years in the rural households than in the urban households. This is evident as the number of births in the rural area is more than the number of births in the urban areas. The urban statistics shows that $22 \%$ of the population are Muslims, while $78 \%$ are Christians. Comparing the rural and urban statistic indicate that there are more Muslims in the rural areas than in urban areas. Concerning ethnicity, the descriptive statistics shows that $3.1 \%$ of the population is made up of pygmies in the urban subsample. Comparing with the rural statistics show that there are more pygmies are found in the rural areas than in the urban areas.

This pygmy ethnic group represent $5.2 \%$ of the population in the rural subsample and $3.1 \%$ in the urban subsample, indicating that more pygmies are found in the rural areas than in the urban areas.

5.2. Logit Regression Results of the Determinant of Female Labour Force Participation (FLFP), for Both Overall and for Sub Samples

Table-5. Overall Results of the Determinants of FLFP.

\begin{tabular}{|c|c|c|c|}
\hline Independent variables (mother working) & Coefficients & Odd ratios & t-statistics \\
\hline No education( reference category) & - & - & - \\
\hline Primary education & $0.6863^{* * * *}$ & 1.9864 & 10.46 \\
\hline Secondary education & $0.2585^{* * * *}$ & 1.2950 & 3.25 \\
\hline university education & $0.3192^{* * *}$ & 1.3761 & 2.02 \\
\hline birth in past year & $-.2184^{* * * *}$ & .80384 & -4.83 \\
\hline age of mother & $0.0519^{* * * *}$ & 1.0533 & 8.78 \\
\hline number females & $0.0440^{* * * *}$ & 1.0450 & 2.61 \\
\hline husband not working & 0.1288 & 1.1375 & 0.40 \\
\hline Married & 0.0046 & 1.0046 & 0.08 \\
\hline \multicolumn{4}{|l|}{ Socio economic status } \\
\hline Rich ( reference category) & - & - & - \\
\hline Poor & $0.7779^{* * * *}$ & 2.1770 & 13.76 \\
\hline children under five & -.0227 & 0.9775 & -1.35 \\
\hline Muslim & $-.9347^{*} * *$ & 0.3927 & -16.33 \\
\hline Ethnicity (Pygmy) & $0.4874^{* * * *}$ & 1.6281 & 3.38 \\
\hline Number of observations & 10905 & & \\
\hline LR $\operatorname{chi} 2(12)[\operatorname{Prob}>\operatorname{chi} 2]$ & $1215.49(0.0000)$ & & \\
\hline Loglikelihood & -5692.838 & & \\
\hline Pseudo R2 & 0.0965 & & \\
\hline
\end{tabular}

Source: Computed by author using DHS 2011.

Note: ${ }^{*}, * * * * *$ represent $10 \%, 5 \%$ and $1 \%$ levels of significance respectively.

Table 5 presents the correlates of female labour force participation in Cameroon. From Table 5, it is observed that the levels of education of the mother relate positively and significantly with female labour force participation in Cameroon for those with primary level of education and starts reducing for those with secondary education as well as university education. Specifically, the odd ratio of 1.98 shows that a woman who has attended primary school has a $98 \%$ more chances of participating (working) in the labour market compared to a woman who is not educated. Similarly the odd ratio of 1.53 for secondary education shows that a woman who has attained the secondary level has a 53\% more chances of working in the labour market compared to their counterparts with no secondary education. Nevertheless, the odd ratio of 1.38 indicate that a woman who has attained university education has $38 \%$ more chances of getting a job and participating in the labour market than those without university education. We therefore realise that the higher the level of education especially after the primary level, the lesser the woman's chances of participating in the labour market. This is evident in Cameroon where we find a majority of those with the basic level of education working in most of the service sectors, while those with higher certificates may not have a job because of the scarcity and the very high competition in the few available jobs. Higher certificate holders will not want to take jobs of lower qualification, regarding it as degrading given the number of years they have put in studying. This result is contrary to those of Lisa, Dowling, and Christopher (2001); Shahidu (1990).

The variable number of births in the past year is negatively and significantly related to female labour force participation, this implies that the higher the number of births in the past year, the lesser the chances of the woman to participate in the labour market. Essentially, the odd ratio of 0.803 indicates that a woman who 
has given birth to many children in the past year has $19.7 \%$ less chances of participating (working) in the labour market, compared to a woman who has given birth to less children, other variables held constant. This result is feasible because a woman who has delivered many children in one year will have to devote more attention, time and care to these children, hence reducing her chances of involving in employment. This result corroborate with those of Noelia (2009); Kuepie et al. (2013).

The age of the mother is positively and significantly related to female labour force participation. Apparently, this is an indication that a woman of a particular age (elderly woman) has more opportunities of participating in the job market. Consequently the odd ratio of 1.05 confirms the fact that an elderly woman has a $5 \%$ likelihood of effectively participating in the labour market than a younger woman. This result is realistic because most employers will prefer elderly women, who are more responsible, focused and have more experience than younger women who still have other goals to pursue, like education, getting married etc. which distracts them more often than not from their work. This finding is in line with the work of Munch, Wijnbergen, and Lejour (2009); Mujuhid (2014).

The variable number of females in the household is observed to be positively related to female labour force participation. Eventually, this implies that the more the number of a woman to participate in the labour market. Therefore, the odd ratio of 1.05 , show that the presence of females in the household has a $4.5 \%$ more chances of a woman to actually participate in labour market, compared to households with lesser number of females. This is discernible as these female children will assist and do most of the works that the woman would have done provided she was not working. Thus the woman is able to work in the job market because of the assistance given her at home by these females.

Also, husband not working has a positive relationship with female labour force participation. This projects that a woman, whose husband is not working has a likelihood of participating in the labour market. Specifically the odd ratio of 1.14 is an indication that a woman whose husband is not working has a $14 \%$ more chance of participating in the job market, than a woman whose husband is working. This may be probably so because a husband who is not working will obviously assist the wife at home, and as such she will devote more time to her job, than would have been the case if the husband was working.

The fact that a woman is married is positively and significantly related to female labour force participation. This therefore implies that married women have more chances of participating in the labour market. Essentially the odd ratio of 1.004portrays that a married woman has a $0.4 \%$ more chances of participating in the labour market, than a woman who is not married. Married women are more stable than unmarried women and handle their job with a lot of care and respect. That is why most employers prefer to employ married than unmarried women. The labour force participation of married women is motivated by the fact that these women desire to provide their families with higher standards of living. Therefore improving the welfare of families is a priority to most women, and for this reason women look for jobs implying that female labour force participation has a positive impact on cost of living. This result is in tandem to the work of Emery and Ferrer (2009); Fosu (1999).

Concerning the socio economic status of households, our results show a positive and significant relationship with female labour force participation. Interestingly, the odd ratios of 2.17 indicate that mothers in poor households/poverty situation have a higher likelihood of working in the labour market compared to those in rich households. This is evident as mothers in poverty situation have to fetch for sources of livelihood to keep the family moving. Given the fact that most poor households are usually found in the rural areas, characterized by the presence of many children, and deteriorating living environment. Therefore relying on a single income is not sufficient, and a more reason why women should get involved in jobs. This result tie with those of Hosny (2007); Bagozzi and Vanloo (1991); Ningaye and Njong (2015).

For children under five years of age, the variable is negatively and significantly related to female labour force participation. It is obvious that a household with many children under five need more attention and care and will eventually reduce the mother's chances of job participation. Specifically the odd ratio of 0.98 is an indication that a woman who has many children who are less than five years has $2 \%$ less chances of participating in the job market. This is evident as these under five children need more care and attention from the mother, who has to make a lot of sacrifices like forgoing a job to cater for them and creating an unenabling environment for her job. This result is in conformity with the work of Rondinelli and Zizza (2011).

The variable religion (Muslim) is negatively and significantly related to FLFP. This is evident as very few Muslims participate in jobs. Specifically the odd ratio of 0.39 indicates that a Muslim woman has a $61 \%$ less chances of participating in the job market. This is evident as the Muslim tradition forbids their wives from working. Considering the variable ethnicity, it has a positive and significant relationship with FLFP. This is likely due to the fact that in the past pygmies were very shy and lived a primitive kind of life style, but in recent time they have opened up to be educated and participate in jobs. Therefore the odd ratio of 1.63 indicates that women from such ethnic groups have $63 \%$ more chances of participating in the labour market. This is evident as the pygmies are being encouraged to participate in jobs by giving them a priority place during competition for jobs. 


\subsection{Subsample Results}

Frome Table 6, sign of the levels of education (primary secondary and university) in the rural and urban sub samples is same (positive) as in the overall sample. Interestingly, we observe that a woman who is educated in the rural area has more chances of working in the labour market compared to her counterpart in the urban area. This may be because most women in the rural area forgo their education for marriage. Hence it is rare to find educated women in the rural area as a result the few educated women in the rural area easily get jobs compared to those in the urban area where we find more educated women who will have to attain certain criteria (such as job experience, network etc) before getting a job. This result is in tandem with the works of (Shahidu, 1990; Sher, 2014).

Births in the past year have the same sign (negative) in the overall sample as in the rural and urban subsamples. But then, we realise that a woman in the urban area who has had more births in the past year has lesser chances of participating in the labour market, than a woman in the rural area faced with this same situation. This is so because in the rural area, we find idle women and girls who can always take care of these children while the mother goes to work, but in the urban area every woman is busy doing something so as to meet up with the cost of living while most young girls pursue their education. Therefore, rural fertility is higher than urban fertility. This result corroborate with those of Ma (2016); Westoff (1994).

Table-6. Sub Sample Results of the Determinants of FLFP.

\begin{tabular}{|c|c|c|c|c|c|c|}
\hline \multirow[b]{2}{*}{$\begin{array}{l}\text { Independent variables } \\
\text { (mother working) }\end{array}$} & \multicolumn{3}{|c|}{ Urban subsample } & \multicolumn{3}{|c|}{ Rural subsample } \\
\hline & Coefficients & $\begin{array}{l}\text { Odd } \\
\text { ratios }\end{array}$ & t-statistics & Coefficients & $\begin{array}{l}\text { Odd } \\
\text { ratios }\end{array}$ & t-statistics \\
\hline No education & - & - & - & - & - & - \\
\hline Primary education & $0.6294^{* * * *}$ & 1.8765 & 5.38 & $0.6943^{* * * *}$ & 2.0024 & 8.54 \\
\hline Secondary education & $0.2469^{* *}$ & 1.2801 & 1.96 & $0.4625 * * *$ & 1.5881 & 3.96 \\
\hline university education & $0.5606^{* * * *}$ & 1.7516 & 2.88 & -0.2924 & 0.7465 & -0.71 \\
\hline births in past year & $-.3026^{* * *}$ & .73891 & -4.56 & $-.1495^{* *}$ & 0.8611 & -2.37 \\
\hline age of mother & $0.0713^{* * * *}$ & 1.0739 & 8.29 & $0.0435^{* * * *}$ & 1.0445 & 5.19 \\
\hline Number of females & $0.0450^{*}$ & 1.0461 & 1.69 & 0.0311 & 1.0316 & 1.38 \\
\hline Husband not working & -.17866 & 0.8364 & -0.43 & 0.8061 & 2.2392 & 1.27 \\
\hline Married & $-.1916^{* *}$ & 0.8256 & -2.47 & $0.3393^{* * * *}$ & 1.4040 & 3.84 \\
\hline \multicolumn{7}{|l|}{ Socio economic status } \\
\hline $\begin{array}{ll}\text { Rich } & \text { (reference } \\
\text { category) } & \\
\end{array}$ & - & - & - & - & - & - \\
\hline Poor & 0.5822 & 1.7899 & 2.88 & $0.2574 * * *$ & 1.2936 & 3.14 \\
\hline children under five & $-.0852^{* * *} *$ & 0.9183 & -3.03 & -.0151 & 0.9847 & -0.70 \\
\hline Religion & $-.5895 * * *$ & 0.5546 & -6.40 & $-1.1469^{* * * *}$ & 0.3176 & -15.34 \\
\hline Ethnicity & 0.1817 & 1.1992 & 0.89 & $0.8200^{* * * *}$ & 2.2706 & 3.66 \\
\hline Number of observations & 4272 & & & 6633 & & \\
\hline $\begin{array}{ll}\text { LR } & \operatorname{chi} 2(12) \\
{[\text { Prob }>\text { chi2 }]} & \end{array}$ & $426.47(0.0000)$ & & & $\begin{array}{l}670.85(0.000 \\
0)\end{array}$ & & \\
\hline Loglikelihood & -2581.0757 & & & -3004.9841 & & \\
\hline Pseudo R2 & 0.0763 & & & 0.1004 & & \\
\hline
\end{tabular}

Source: Computed by author using DHS 2011.

Note: ${ }^{*}, * *, * * *$ represent $10 \%, 5 \%$ and $1 \%$ levels of significance respectively.

Looking at the age of the mother, the sign remains the same in the overall sample (positive) as in the rural and urban subsamples. Specifically it is seen that an elderly woman has more chances of working in the urban area than her counterpart in the rural area. This is realistic because an elderly woman in the urban area must have put in more years of education and have gathered more experienced than her counterpart in the rural area who might have spend fewer years in school and thus having little or no job experienced. This result corresponds to those of Akono and Nanfosso (2013).

We observe the same sign (positive) for number of females in the overall sample as in the rural and urban subsamples. There is a tendency that with the presence of more females in the house, a woman in the urban area will have more chances of working than a woman in the rural area. There is availability of job variety in the urban areas compared to rural areas. Therefore if there are many females in the urban household they will assist the woman in taking care of the children and as a result she can easily pick up a job. But then with job constraints in the rural areas, the number of females may be many in the household but yet the woman finds it difficult to get a job.

Considering the variable husband not working, we find the sign (positive) in the overall sample is same as in the rural subsample. Unfortunately, we realise a negative sign in the urban subsample indicating that a woman in the urban area whose husband is not working has lesser chances of participating in the labour market, while her counterpart in the rural area has more chances. This is evident because a husband who is not 
working in the urban area would surely be searching for a job, indicating a temporal situation while in the rural area the husband who is not working may permanently stay at home or do less demanding jobs and still takes good care of the home thereby increase his wife's chances of working.

The variable married has the same sign (positive) in the overall sample as in the rural subsample, but negative in the urban subsample. Apparently, these results signify that a married woman in the urban area has lesser chances of working while a married woman in the urban area has more chances. Reason being that married women in the urban area have a lot of commitments (such as expectations from the village, high rents and cost of living in towns etc), while those in the rural area have less commitments and also have many people to always assist them at home thus increasing their opportunity of working. This result is in conformity with that of Fazio, Connelly, Lan, and Tang (2009).

The socio economic status of households has the same sign (positive) in the overall sample, as in the rural and urban subsamples. It shows that women faced with poverty situation in the urban area will search for jobs more than those in the rural area. This is likely so, because of the high cost of living in the urban areas which usually provokes the search for jobs in this area. This reflects the results of (Masika, Arjan, \& Badden, 1997).

The presence of children under five years of age has the same sign (negative) in the overall sample as in the urban and rural subsamples. Consequently, we find that the presence of under -five children in the urban household limits the chances of urban woman working than it does for woman in the same situation in the rural area. This may be evident because under- five children constitute that part of the population that requires much attention and care. In the rural area we easily find people who are always ready and available to give this assistance, whereas in the urban areas, it is very difficult to find such people because of their busy schedule, thus leaving an urban woman with lesser chances of participating in the job market (Fang, Eggleston, Rizzo, \& Zeckhaser, 2013).

The variable religion is negative in the overall sample as well as in the rural and urban subsamples, indicating that Muslims participate less in the labour market than Christians. This is evident since the Muslim customs and tradition hinders their women from working. They have the belief that a woman's place is to stay at home taking care of the children, coupled with the fact that Islam endorses pronatalistic practices which leads to more births and as such hindering their women from participating in the job market (Adegbola, 1988; Guiso et al., 2003; Hannah et al., 2014).

Ethnicity has a positive relationship with female labour force participation. The pygmies have become more enlightened and educated that they have been increasingly participating in jobs. The results show specifically that the participation of pygmies in the rural areas is greater than their participation in the urban areas. This is attributed to the fact that a majority of pygmies are found in the rural area and most often they do not want to move to urban areas, that is why they are limited to jobs only in the rural areas.

\section{Conclusion and Policy Implications}

The study was focused on investigating the determinants of female labour participation in Cameroon. It employed a logistic regression given the dichotomous nature of the dependent variable: female labour force participation. The independent variables included the level of education and mother/household characteristics, as well as employability of the husband/partner. The primary level of education has a positive impact on female labour force participation. The higher the level of education, the lesser the chance a woman has in participating in the job market.

Eventually, given the fact that a woman who has had fewer births in the past year leaves her with more opportunities of getting a job, indicates that the labour supply of women will increase (Kuepie et al., 2013; Lam \& Duryea, 1999). Elderly women increase the supply of labour, explained by the fact that they have more opportunities in getting a job than younger women since they are favoured compared to younger women. The presence of females in the household will lead to an increase in the supply of labour because they assist the woman in her family work, while she is away. Also the presence of young children aged 0-5 years reduces the woman's chances of getting a job, thus reducing the supply of labour, because she will instead have to devote more time to take care of them and little or no time for work. This is an indication that mother's household characteristics have a positive effect on FLFP as such hypothesis 2 is accepted.

The fact that the partner is not working has a positive relationship with fertility which is an implication that husband's employability will greatly affect female participation in the labour market. Therefore we accept hypotheses 1. Religion (Islam), which is practised by the Muslims relates negatively with FLFP implying that Muslims participate less in the labour market than Christians. We therefore accept our hypothesis 3.

It is important for policy makers to understand women's decision to supply labour to the market as well as the factors that enable them to either participate or not in the job market. This will help policy makers to efficiently help an economy to develop and remain healthy. Given the hindering factors to female labour participation in Cameroon, the government and other stakeholders should put in place measures to improve on female labour force participation supply. In the past there have been positive supports to women who are relentless in their struggle for equality from the United Nations International Conference on women which began in 1985. These conferences and regional follow up conferences have provided a forum for African women to pursue their own interest for first time in modern African history. Also the pressure from the World 
Bank and International Labour Organisation and others has pushed many African governments to create special ministries designated for women's welfare, for example women empowerment centres. The Cameroon government in 2009 in her current public policy action aimed at introducing programs to create employment opportunities for the most underprivileged social groups especially women in the public service in order to supplement decent employment. Despite these measures by the Cameroon government, the level of female participation in the labour market in Cameroon remains comparatively small, and for this reason the government should do everything within its capacity to increase the participation of women in the labour force. She can achieve this goal by:

Given that the number of children a woman has had in the past year, coupled with the presence of children aged 0-5years greatly affects her participation in the labour market, the government of Cameroon should work hand in glove with the Ministry of Public Health in sensitizing the population of the need of family planning. Teams should be formed and sent to rural areas where the number of births are more, probably because of their ignorance on birth control to wipe out the idea of having many children that they cannot care for and advising them on the best method of birth control.

Education, especially that of women is very important in any country, because they are the first teachers of a child at home. For this reason, the government should encourage female education at all levels and especially at the primary level. By so doing, the practice of giving out young girls to marriage in most communities shall be eradicated, and therefore more young girls will be able to further their education and get better jobs in the future. The government should also encourage female education by granting scholarships to girls who perform academically and especially in the sciences, and also provide funding for the education of females taking into consideration the minority group (the Muslim girls) who are usually not allowed to acquire education according to their customs and tradition., improve educational quality through an integrated approach that includes teacher training, parental education, and community involvement in school management.

Muslims should be encouraged to participate in the labour force especially in homes where the father's single income cannot sustain the family. If this is done, it will help to alleviate poverty.

In order to tackle the problem of the caused by the presence of children under 5 on female participation in the labour force, a policy implication should be to offer affordable child care centers and facilities to take care of children who are above one year, thus encouraging women to participate in the labour market.

\section{References}

Ackah, C., Ahiadeke, C., \& Fenny, A. P. (2009). Determinant of female labour force participation Ghana. The Institute of Statistical, Social and Economic Research, University of Ghana.

Addison, T. (1993). Employment and earnings. In L. Demery M., Ferroni C., Grootaert J. and Wong-Valle, eds, understanding the social effect of policy reform. Washington D.C: The World Bank.

Adegbola, O. (1988). Religion and reproduction in Sub-Saharan Africa. Paper presented at the Dakar, Senegal, Nov 7-12., Paper Presented at the African Population Conference.

Akono, C. Z., \& Nanfosso, R. (2013). Private returns to education in urban Cameroon. University of Yaounde II, Cameroon, Faculty of Economics and Management. May (2013).

Andrei, T., Mirica, A., Teodorescu, D., \& Dascalu, E. (2016). Main determinants of labour force participation in the case of Metropolitan Roma people. Romanian Journal of Economic Forecasting, 19(3), 144-163.

Atieno, R. (2006). Female participation in the labour market. The case of the informal sector in Kenya. Institute for Development Studies University of Nairobi AERC Research Paper No. 157.

Bagozzi, R. P., \& Vanloo, M. F. (1991). A purposeful behavior theory of work and family size decisions. Journal of Academy and Marketing Science, 27, 184-206.

Baridam, D. M. (1996). Determinants of female labour force participation and family size in Nigeria. Indian Journal of Industrial Relations, 32(2), $204-215$.

Bibi, A., \& Afzal, A. (2012). Determinants of married women labour force participation in Wah Cantt: A descriptive analysis. Academic Research International Journal, 2(1), 599-622

Boserup, E. (1970). Therole of women in economic development. New York: St Martin London; Earth Scan.

Boserup, E. (1990). Population, the status of women and rural development. Rural development and population institutions and policy. New York: Oxford University Press. Population and Development Review, 15.

Chadwick, B. A., \& Brent, L. T. (1993). Religiousity and delinquency among LDs adolescents. Journal for the Scientific Study of Religion, 32(1), 51-67.

Emery, J. C. H., \& Ferrer, A. (2009). Marriage market imbalance and labor force participation of Canadian women. Review of Economics of the Household, 7(1), 43-57.

Even, W. E., \& Macpherson, D. A. (1990). Plant size and the decline of unionism. Economics Letters, 32(4), 393-398.

Fang, H., Eggleston, K. N., Rizzo, J. A., \& Zeckhaser, R. (2013). Jobs and kids: Female employment and fertility in China. IZA Journal of Labour and Development, 3, 12.

Faridi, M. Z., Chudhry, I. S., \& Malik, M. S. (2011). Why women are self-employed. Empirical evidence from Pakistan. International Journal of Economics and Finance, 3(1), 198-207.

Fatma, G. L., \& Eyza, B. (2005). Determinants of female labour force participation. A study of North Cyprus. Review of Social Economic and Business Studies, 5, 209-226.

Fazio, M. M., Connelly, R., Lan, C., \& Tang, L. (2009). Childcare, eldercare and labour force participation of married woman in urban China 1982-2000. IZA Discussion Paper No. 4204 June 2009. 
Fosu, A. K. (1999). Cost of living and labour force participation: Married women in urban labour markets. Journal of Labour Research, 20(2), 219-232.

Guiso, L., Sapienza, P., \& Zingales, L. (2003). Peoples opium?. Religion and economic attitudes. Peoples Journal of Monetary Economics, 50(1), 225-282.

H'madoun, M. (2010). Religion and labour force participation of women. Faculty of applied Economics University of Antwerp.

Hannah, G. L., Ayodo, T. M. O., Tikoko, B., \& Enose, M. W. (2014). Socio -cultural factors that hinder women's access to management positions in government grant aided secondary schools in Uganda. The case of Eastern region. Educational Research, 5(7), $241-250$.

Hendy, R. (2011). On marriage and labor market transitions. A structural dynamic model, Unpublished 2011.

Hosny, S. H. (2007). Modelling the relationship between poverty and female working status in Egypt Cairo University Department of Economics.

International Monetary Fund. (2013). Women, work and the economy. Macroeconomic gains from gender equity; September 2013 Strategy, Policy Review and Fiscal Affairs Department.

Iweagu, H., Yuni, D. N., Nwokolo, C., \& Bulus, A. (2015). Determinant of female labour force participation in Nigeria. The rural / urban dichotomy. Journal of Economics and Sustainable Development 6(10), 212-219.

Jain, A. K. (1985). Determinants of regional variations in infant mortality and rural India. Journal of Population Studies, $39(3), 407-424$

Khadim, Z., \& Akram, W. (2013). Female labour force participation in the formal sector: An empirical analysis from PSLM (2007-2008). Middle East Journal of Scientific Research, 14(11), 1480- 1488.

Killingworth, M. R., \& Heckman, J. J. (1986). Female labour supply (Vol. 1, pp. 103-204). A survey in Ashenfelter O. (ed): Handbook of Labor Economics, Amsterdam; North Holland.

Kinoshita, Y., \& Fang, G. (2015). What can boost female labor force participation in Asia? IMF Working Paper $\mathrm{WP} / 15 / 56$

Kuepie, M., Dzossa, A., \& Kelodjoue, S. (2013). Determinants of labor market gender inequalities in Cameroon, Senegal and Mali: the role of human capital and the fertility burden, Working Paper No. 203-08 June 2013

Lam, D., \& Duryea, J. (1999). Effects of schooling on fertility labour supply and investment in children with evidence from Brazil. The Journal of Human Resource, 34(1), 160-192.

Lisa, A. C., Dowling, J. M., \& Christopher, W. (2001). Education and labour market participation of women in Asia: Evidence from five countries. Journal of Development and Cultural Change, 49(3), 459-477.

Lisaniler, F. G., \& Bhatti, F. (2005). Determinants of female labour force participation: A study of North Cyprus. Review of Social, Economic and Business Studies, 5(6), 209-226.

Ma, L. J. (2016). Female labour force participation and second birth rates in South Korea. Journal of Population Research, 33(2), 173-195.

Maglad, N. A. (1998). Female labour supply in Sudan. Department of Economics, Gezira University Sudan. African Economic Research Consortium paper 30. March 1998.

Masika, R., Arjan, D. H., \& Badden, S. (1997). Urbanization and urban poverty: A gender analysis. Institute of Development Studies, University of Sussex ISBN 1858643473.

Meltem, D., \& Kırdar, M. G. (2010). Determinants of and trends in labor force participation of women in Turkey: World Bank.

Mlatsheni, C., \& Leibbrandt, M. (2001). The role of education and fertility in the participation and employment of African women in South Africa. Development Policy Research unit: Working Paper No. 01. pp: 54.

Mujuhid, N. (2014). Determinants of female labour force participation: A micro analysis of Pakistan. International Journal of Economics and Empirical Research, 2(95), 211-220.

Munch, A. J., Wijnbergen, S. V., \& Lejour, A. (2009). Education and labour market activity of women. An age group specific empirical analysis. Discussion Paper No. 11

Ngeh, E. T. (2016). Female labour force participation and sectional choices for females in Cameroonian labor market. International Journal of Innovation and Scientific Research, 21(1), 118-129.

Ningaye, P., \& Njong, A. M. (2015). Determinants and spatial distribution of multidementional poverty in Cameroon. International Journal of Social Science Studies, 3(1), 91-103.

Njimanted, G. F., \& Mukete, E. M. (2016a). The implication of female labour force participation on economic growth in Cameroon. International Journal of Development and Economic Sustainability, 4(1), 34-47.

Njimanted, G. F., \& Mukete, E. M. (2016b). The implication of female labour participation on economic growth in Cameroon. International Journal of Development and Sustainability, 4(1), 34-47.

Noelia, P. R. (2009). The effects of female labour force participation on fertility spacing. Department of Economics Texas A and $M$ University.

Ntuli, M. (2007). Determinants of South African women's labour force participation 1995- 2004. University of Cape Town and IZA Discussion Paper No. 3119.

Olowa, O. A., \& Adeoti, A. L. (2014). Effect o Education status of women on market participation in rural Nigeria. American Journal of Economics, 4(1), 72-81.

Olukemi, I. L. (2008). Female labour force participation in Nigeria: Determinants and trends. Oxford Business and Economic Conference Programme.

Olusoji, M. O. (2006). Determinants of female labour supply in Nigeria. Nigerian Journal of Economic and Social Sciences, $48(1)$.

Oluwasey, S. D. (2013). Determinants of female labour force participation in Switzerland. European Journal of Applied Social Sciences Research, 1(2), 58-66.

Psacharopoulos, G., \& Tzannatos, Z. (1989). Female labor force participation: An international perspective. World Bank Research Observer, 4(2), 187-201. 
Rondinelli, C., \& Zizza, R. (2011). Non persistent effect of fertility on female labour supply. Institute for Social and Economic Research, Economic and Social Research Council no. 2011-04 January 2011.

Ruhm, C. J. (1998). The economic consequences of parental leave mandates; lessons from Europe. The Quarterly Journal of Economics, 113(1), 285-317.

Sackey, H. A. (2005). Female labour force participation in Ghana: The effects of education, AERC research paper No. 150. Narobi Kenya: The Regal Press.

Shahidu, R. K. (1990). Labour market participation returns to education and male female wage differences in Peru. Washington DC (1818H St. NW Washington) 20433). World Bank Population and Human Resource Department (1990).

Sher, V. (2014). Female labour force participation in developing countries. International Labour Organization, (India and IZA Germany).

Siphambe, H., \& Motswapong, M. (2010). Female results from the 2005/2006 labour force survey data. Botswana Journal of Economic, 7(11), 65-79.

Steven, K., Andrea, S., \& Evangelia, K. (2014). Why is female labour force participation declining so sharply in India? ILO Research Paper No. 10.

Sunghee, N. (1991). Determinants of female labour force participation: A study of Seoul, South Korea, 1970-1980. Sociological Forum, 6(4), 641-659.

Surjit, S. B., \& Kaur, R. (2011). Labour force participation of women in India: Some facts, some queries. Asia Research Center, Working Paper No. 40.

Tansel, A. (2001). Economic development and female labour force participation in Turkey. Time series evidence and cross province estimates. Department of Economics. Middle East Technical University.

Tsani, S., Paroussos, L., Fragiadakis, C., Charalambidis, I., \& Capros, P. (2012). Female labour force participation in Southern Mediterranean countries. MEDPRO Technical Report No. 19/December 2012.

United Nations Development Fund UNDP. (2003). Human development indicators 2003. New York: Oxford University Press.

Verena, T. R., Sonam, U., \& Yusraa, B. (2011). The power to choose: Women and labour market decisions in Mauritus. Department of Economics and Statistics, University of Mauritus.

Viljeon, D. J., \& Dunga, S. T. (2013). Determining the factors that influence female Unemployment in a South African township. International Journal of Social Sciences and Humanity Studies, 5(1), 63-72.

Westoff, C. F. (1994). Reproductive preferences and future fertility ion developing countries. In the future population of the world: What can we know today? Edited by W.Lutz, 83-97 UK. Earthscan Publications Limited.

World Bank. (2013). World development indicators 2013. Washington, DC: World Bank. Available from: 10.1596/978-082 13-9824-1. License: CreativeCommons Attribution CC BY 3.0.

Yakubo, A. Y. (2008). Factors influencing female labour force participation in South Africa. The African Statistics Journal, $11,85-104$.

Yuko, K., \& Fang, G. (2015). What can boost female labour force participation in Asia? IMF Working Paper No. 15. pp: 56.

Zama-Akono, C. M. (2009). Female labour force participation in urban Cameroon. Do children and health status really matter? Center for the Study of African Economies Oxford. 